\title{
Potencialidades do Geossítio Paredões de Janeiro, Parque Nacional de Ubajara, Ceará, Brasil: a geomorfologia como patrimônio
}

\author{
Potentiality of Paredões de Janeiro Geosite, Ubajara National \\ Park, Ceará, Brazil: geomorphology as heritage
}

Suedio Alves Meira, Doutorando em Geografia, Programa de Pós-graduação em Geografia, Universidade Federal do Ceará, Brasil, suediomeira@gmail.com

(D) http://orcid.org/0000-0001-9059-8787

Marcos António Leite do Nascimento, Departamento de Geologia, Universidade Federal do Rio Grande do Norte, Brasil, marcos@geologia.ufrn.br

(D) http://orcid.org/0000-0002-8158-7186

Edson Vicente da Silva, Departamento de Geografia, Universidade Federal do Ceará, Brasil, cacauceara@gmail.com

(1) http://orcid.org/0000-0001-5688-750X

Resumo: O Geossítio Paredões de Janeiro (GPJ), Tianguá (Ceará), reúne algumas das mais espetaculares feições geomorfológicas do Parque Nacional de Ubajara (PNU). Contempla o contato do Glint da Ibiapaba com a Depressão Sertaneja, fendas estruturais e uma cachoeira. Porém, apesar do potencial, a área não dispõe de ações diretas de conservação e trabalhos científicos. O presente trabalho tem por objetivo realizar o inventário dos locais de interesse geológico, a sua avaliação quantitativa e proposta de estratégias de conservação, valorização e divulgação para o GPJ. No GPJ foram inventariados dois mirantes, quatro fendas estruturais e uma cachoeira. A avaliação quantitativa classificou o GPJ como de relevância nacional, com valor científico de 285, educativo de 305 e turístico de 255. Quanto à valorização foram selecionadas a Pedra do Espia e a Fenda Norte para a confecção de painéis interpretativos. Para a divulgação, é proposto um cartão postal e sua inserção em três roteiros geoturísticos. A presente pesquisa demonstra de forma quantitativa e qualitativa os valores científicos, educativos e turísticos do GPJ, erguendo esse espaço enquanto prioritário para a instituição de ações de conservação e educação ambiental no contexto do PNU.

Palavras-chave: Geopatrimônio; Geoconservação; Geodiversidade; Geoturismo.

Abstract: The Paredões de Janeiro geosite (GPJ), Tianguá (Ceará), presents some of the most spectacular land forms in the Ubajara National Park (PNU). It includes the connection between Ibiapaba Glint and Sertaneja Surfaces, structural geomorphological cracks and a waterfall. Besides its potential this area doesn't dispose of direct conservation actions nor scientific work. In this context, we aim to produce the inventory, the quantitative evaluation and to propose valorization strategies for the geoheritage in the GPJ, as an asset to the environmental planning. At the GPJ we inventoried two viewpoints, four structural geomorphological cracks and a waterfall. The quantitative evaluation classified the GPU as a nationally relevant site with scientific value of 285 , educational value of 305 and touristic value of 255. Concerning the valorisation, we selected the Pedra do Espia and the Fenda Norte as subject for interpretative panels. For promotion, we propose a postcard and its insertion in three geotouristic routes. The present research shows in quantitative and qualitative aspects the GPJ scientific, educational and touristic values, raising this space as priority for creation of conservation and environmental education actions in the PNU context.

Keywords: Geoheritage; Geoconservation; Geodiversity; Geotourism. 


\section{Introdução}

O crescimento, a partir de 1990, dos trabalhos relacionados à temática da Geodiversidade fez com que esse campo fosse considerado um novo paradigma conceitual e metodológico no contexto das Geociências (Gray, 2008). Os estudos partem do entendimento da geodiversidade enquanto a diversidade de elementos abióticos e os processos a eles associados, os quais configuram a base para 0 desenvolvimento da vida (Nieto, 2001). Por sua vez, o geopatrimônio compreende os elementos da geodiversidade que apresentam valor excepcional de acordo aos valores científico, educativo, estético, cultural ou outros (Carcavilla et al., 2008). Salienta-se que o geopatrimônio funciona enquanto um conceito que abarca toda uma gama de categorias temáticas, dentre as quais o patrimônio geomorfológico, petrológico, hidrológico, espeleológico, entre outros (Meira, Morais, 2016). Já a geoconservação configura o conjunto de atividades orientadas à conservação dos elementos que compõem o geopatrimônio de um determinado local (Brilha, 2005).

Um dos esforços iniciais, quando tomado especificamente ações relacionadas ao geopatrimônio, compreende o inventário de locais geológicos com características excepcionais, aqui entendido de forma ampla como geossítios. O inventário de geossítios é o ato de tornar conhecido, para o meio acadêmico e demais nichos da sociedade, uma determinada feição abiótica bem delimitada geograficamente. É mostrar, por meio da caracterização dos seus constituintes abióticos, da descrição dos processos evolutivos e do apontamento das suas potencialidades, que esse lugar específico se distingue dos demais enquanto registro da história do Planeta Terra. Sendo assim, o inventário de geossítios ergue-se como estímulo ao desenvolvimento do conhecimento cientifico e à conservação da natureza, devendo ser incentivado em diferentes escalas e focos de análise.

Para locais salientados na literatura científica a definição enquanto geossítio pode trazer visibilidade no campo acadêmico e ergue-se enquanto incentivo à gestão territorial. Por sua vez, em locais "desconhecidos" pela ciência, o inventário configura um impulso ao desenvolvimento de pesquisas e na sensibilização dos gestores locais, ao trazer o entendimento do patrimônio presente visando a máxima que "só se conserva o que se conhece".

O Geossítio Paredões de Janeiro (GPJ), alvo do presente estudo, insere-se no segundo grupo supracitado. Configura uma área onde os aspectos geológicos e geomorfológicos apresentam relevância científica, educativa e cênica, mas sem o desenvolvimento de trabalhos acadêmicos que traduzam as suas potencialidades enquanto registro da evolução geológico-geomorfológica do noroeste cearense.

O GPJ está localizado no município de Tianguá, estado do Ceará, nas coordenadas iniciais (UTM) 284158 Leste e 9590401 Sul, inserido na porção norte do Parque Nacional de Ubajara (Figura 1). O Parque Nacional de Ubajara (PNU) foi criado em 30 de abril de 1959 com a finalidade de garantir a integridade e os processos evolutivos do excepcional conjunto de formações geológicas e biológicas. Atualmente conta 6.288 hectares, dispostos nos municípios cearenses de Frecheirinha, Tianguá 
e Ubajara. A geodiversidade local é caracterizada pelo principal conjunto de feições cársticas do estado Ceará e pelo contato do front do Glint da Ibiapaba e a Depressão Sertaneja, originando feições escarpadas de grande beleza cênica.

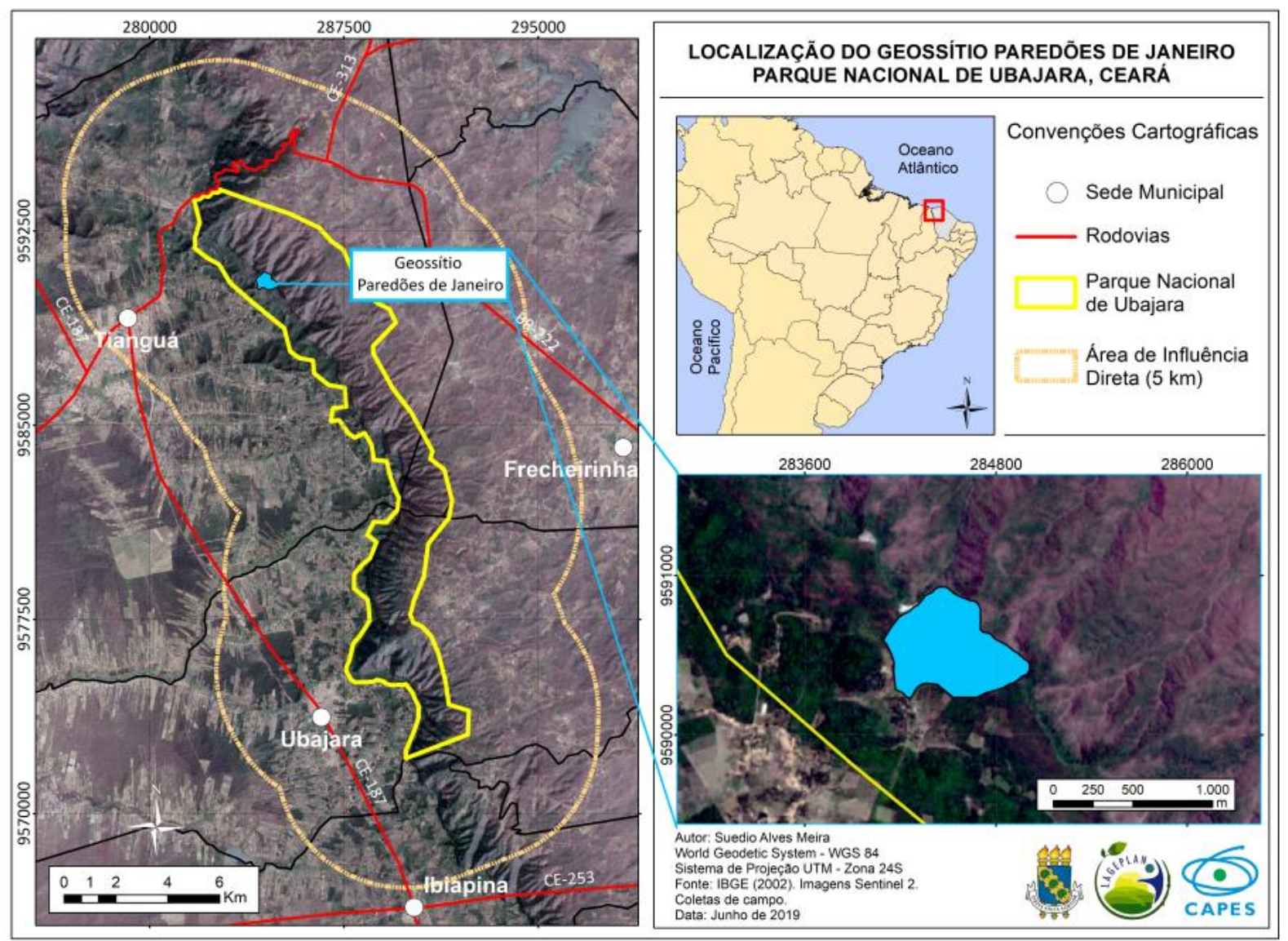

Figura 1: Localização do Geossítio Paredões de Janeiro no contexto da área de pesquisa.

Ante o exposto, objetiva-se realizar o inventário, a avaliação e a proposição de medidas de conservação, valorização e divulgação para o GPJ. Parte-se da premissa que o local apresenta múltiplas potencialidades científicas, educativas e turísticas que podem e devem ser apropriadas pela gestão do PNU no desenvolvimento de suas atividades de conservação ambiental.

\section{Metodologia}

A metodologia empregada compreende uma estratégia de geoconservação (Brilha, 2005), que contempla as etapas do inventário, avaliação quantitativa e a proposição de medidas de conservação, valorização e divulgação para o GPJ1. Primeiramente, foram realizados levantamentos bibliográficos sobre os aspectos ambientais do PNU, dando ênfase às abordagens sobre a geodiversidade. Foram reunidos artigos científicos, monografias, dissertações e teses acerca da borda leste da Bacia do

\footnotetext{
${ }^{1}$ Salienta-se que esse estudo está inserido num esforço maior quanto à pesquisa e ao planejamento do geopatrimônio do PNU, desenvolvido no âmbito da tese de doutorado em Geografia do primeiro autor, intitulada "Planejamento e propostas de valorização do geopatrimônio do Parque Nacional de Ubajara, Ceará, Brasil" (Meira, 2019, no prelo).
} 
Parnaíba. Também foram gerados materiais cartográficos de base, tendo como suporte dados de geologia, hidrografia, solos e imagens de satélite Landsat TM 8 e de radar SRTM (Shuttle Radar Topography Mission). Essa etapa teve como objetivo gerar conhecimento prévio sobre as características geológicas e geomorfológicas, sendo então um auxílio à etapa de inventário.

O inventário dos geossítios foi realizado com foco nos critérios educativo e turístico. Foram utilizadas as metodologias de seleção de locais com caraterísticas superlativas e a definição de categorias temáticas pré-estabelecidas (framework) (Pereira, 2010). Foram definidos três frameworks para o PNU segundo critérios cronoestratigráfico e geomorfológicos, sendo eles: i) Zona com coberturas cenozoicas; ii) Coberturas paleozoicas; iii) Embasamento neoproterozoico. Nos trabalhos de campo do inventário foram realizadas as análises da paisagem. Salienta-se que o GPJ está inserido na categoria temática das coberturas paleozoicas, a qual é caracterizada por: rochas sedimentares das formações Tianguá e Jaicós, pertencentes ao Grupo Serra Grande, e geomorfologia marcada pelo front do Glint da Ibiapaba.

$\mathrm{Na}$ avaliação quantitativa dos geossítios foi adotada o método proposto pelo aplicativo do Sistema de Cadastro e Quantificação de Geossítios e Sítios da Geodiversidade (GEOSSIT), do Serviço Geológico Brasileiro (CPRM, 2018), que configura uma adaptação das metodologias de Garcia-Cortés e Carcavilla-Urquí (2013) e Brilha (2016).

Nas etapas de conservação, valorização e divulgação foram gerados produtos gráficos. Para cada proposta foi construído um plano interpretativo abordando o tema principal (o que interpretar?), elencando objetivos específicos (o que pretende que se conheça? O que pretende que se sinta?), definindo o público alvo e os usos sugeridos (turístico, educativo e/ou científico). Todas as imagens utilizadas foram tratadas quanto a contraste, exposição, sombras, saturação e balanço de brancos e pretos no programa Adobe Lightroom. Já os desenhos do painel interpretativo, cartão postal e do folheto educativo-turístico foram confeccionados por meio do programa Adobe Illustrator CC 2015.

\section{Inventário e caracterização do Geossítio Paredões de Janeiro}

A toponímia do Geossítio Paredões de Janeiro segue a designação popular, sendo uma mescla das suas características geomorfológicas (escarpas e fendas) com aspectos sociais, uma vez que a região é conhecida como Sítio Janeiro. O GPJ é um geossítio área (Fuertez-Gutiérrez, Fernandes-Martinéz, 2010) com 39,7 hectares e apresenta, dentro de um mesmo contexto geológico, diversidade de feições com elevado apelo cênico e educativo, compostas por vistas panorâmicas, fendas, paredões e uma cachoeira. A delimitação do GPJ engloba todas as feições de interesse e áreas no entorno das trilhas de acesso. A demarcação do polígono partiu do começo da trilha, com as coordenadas supracitadas, e se estendeu por um buffer de aproximadamente 150 metros dos principais pontos de interesses, que serão descritos a seguir de forma separada. 
O primeiro ponto de relevância é a Pedra do Espia, um mirante localizado sobre um bloco isolado da escarpa, nas coordenadas (UTM) 284540 Leste e 9590643 Sul e a 746 metros de altitude. No local é possível abordar temas relacionados à evolução geomorfológica quaternária, sendo facilitada a visualização de feições como: escarpas aparentes, frente de recuo erosivo, o entalhe do relevo pela ação fluvial, porções coluviais, superfícies soerguidas e dissecadas do embasamento, a depressão sertaneja e maciços residuais no horizonte (Figura 2). Durante alguns meses do ano é possível visualizar a cachoeira do riacho da Rocha da Rosa, de caráter intermitente.

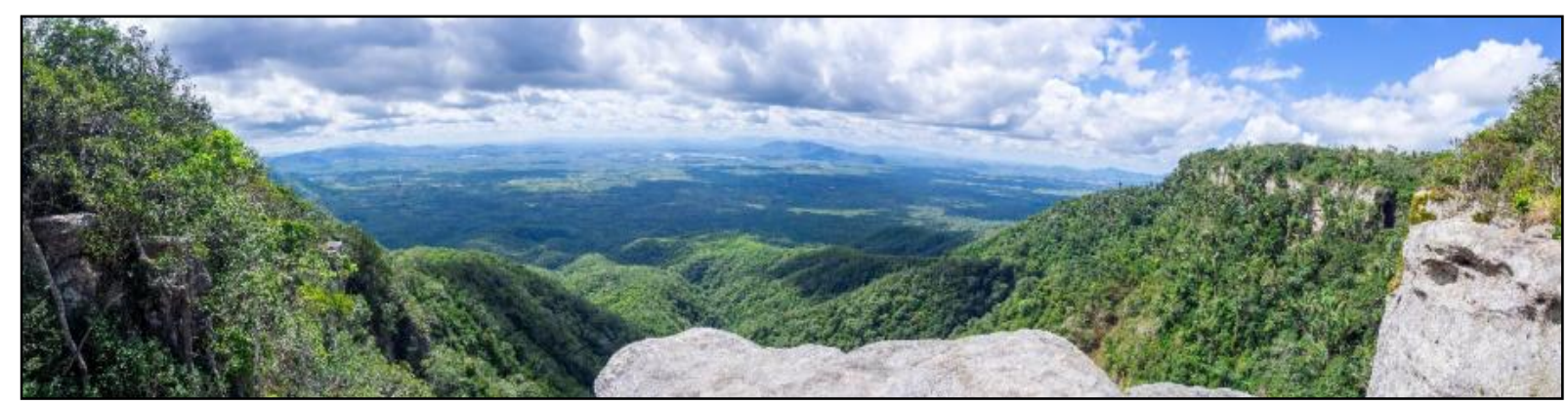

Figura 2: Mirante da Pedra do Espia no Geossítio Paredões de Janeiro.

A litologia do local é caracterizada por arenitos da Formação Tianguá, os quais são acinzentados e mal selecionados (intercalação de seixos e areias grossas), sendo presente concreções/capeamento ferruginoso localizados nas zonas de fraturas da rocha (Figura 3). As fraturas estão seccionadas verticalmente e horizontalmente, apresentam orientação de $350^{\circ}$. Percebe-se que o padrão se repete por todo o bloco da Pedra do Espia e em porções da escarpa.

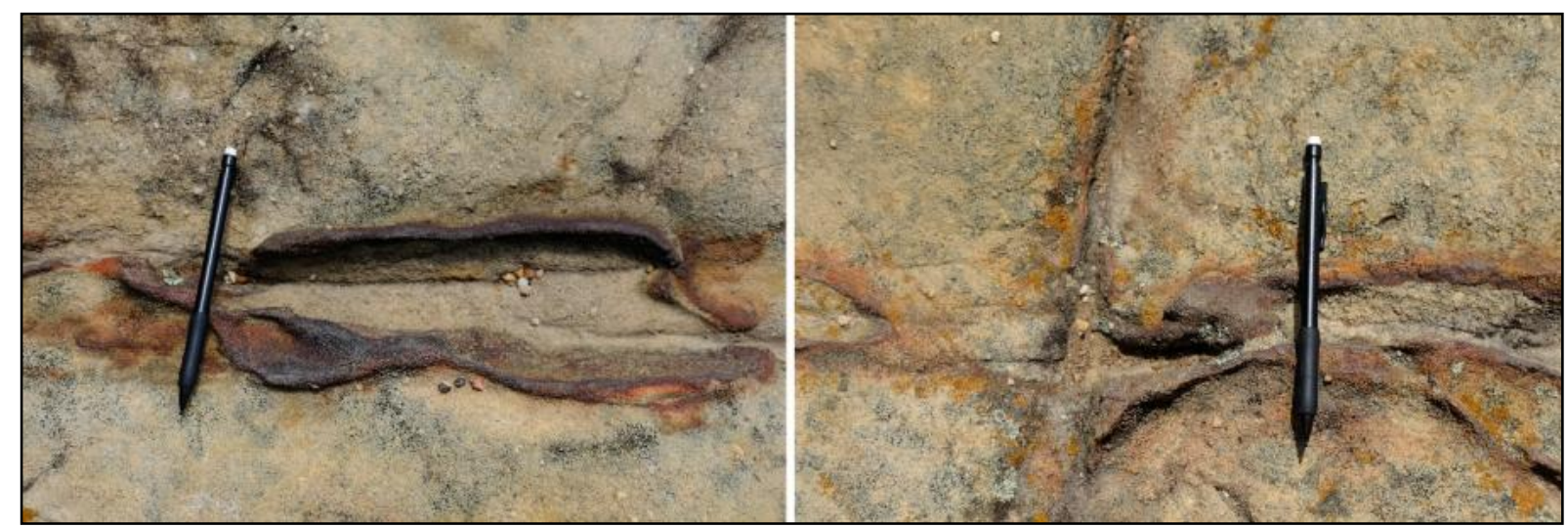

Figura 3: Capeamentos ferruginosos no arenito da Formação Tianguá na Pedra do Espia.

É válido trazer uma caraterização geral da Formação Tianguá, que compreende a unidade intermediária do Grupo Serra Grande, unidade basal da Província Parnaíba. A Formação Tianguá é composta por folhelhos cinza-escuro (bioturbados, sideríticos e carbonáticos), arenitos cinza-claro (variando de fino a médio, feldspáticos), intercalações de siltitos e folhelhos cinza-escuros (bioturbados e micáceos) (Caputo, Lima, 1984; Góes, Feijó, 1994). 
Caputo e Lima (1984) subdividem a Formação Tianguá em três membros, sendo: i) o primeiro composto por folhelho preto a cinza escuro, siderítico, bioturbado ou laminado, síltico; ii) o segundo compreende arenitos de granulometria fina a média, com intercalações de folhelho, feldspático, cinza esbranquiçado; iii) por fim, no terceiro membro estão presentes folhelhos e siltitos intercalados, cinza escuros a verdes, micáceos, sideríticos. A Formação Tianguá se dispõe de forma concordante com a Formação Ipu (base do Grupo Serra Grande) e a Formação Jaicós (última deposição do Grupo Serra Grande) (Caputo, Lima, 1984). É apontada a idade de deposição eosiluriano, tendo como base estudos palinológicos e de macrofósseis, e ambiente de deposição marinho raso (Góes, Feijó, 1994).

No GPJ ocorrem quatro fendas nos arenitos da Formação Tianguá com orientação e lineamento NW-SE, sendo que as fendas apresentam distâncias inferiores a 500 metros entre elas. Duas fendas estão localizadas ao norte da Pedra do Espia, sendo essas denominadas pelo presente autor como "Fenda da Trilha" e "Fenda Norte". As outras duas estão localizadas ao sul do ponto de referência, localizando-se uma na base da cachoeira do riacho da Rocha da Rosa, sendo aqui chamada por "Fenda do riacho da Rocha da Rosa", e a outra mais ao sul, denominada "Fenda Comprida".

As características geomorfológicas das fendas remetem para um controle estrutural. Quando analisado o mapeamento estrutural da CPRM (2014) nota-se a presença, na adjacência norte, da Falha Arapá, disposta sobre o embasamento cristalino da Província Borborema, sendo oriunda de atividades tectônicas do Ciclo Brasiliano (940Ma-490Ma), ou seja, anterior à gênese do Grupo Serra Grande. A área também é próxima ao Lineamento Transbrasiliano (Falha Sobral-Pedro II).

Apesar dos controles estruturais predominantes na área serem anteriores à deposição do Grupo Serra Grande, Moura-Fé (2017, p. 394) expõe que durante a era Mesozoica, especialmente no período Cretáceo, a Ibiapaba passa por um dos processos mais relevantes para sua configuração geomorfológica atual, sendo fruto da fissão do Pangeia e de sua porção meridional (Gondwana), "mais precisamente dos continentes da África e da América do Sul, a qual estabeleceu no Brasil um novo estágio tectônico, o 'estágio de ativação' que levaria à abertura do oceano Atlântico e que originou a margem equatorial brasileira". Esse período, que teve início há $140 \mathrm{Ma}$, foi marcado, segundo Moura-Fé (2017, p. 394, grifo dos autores), por

\footnotetext{
eventos distensionais, remobilização de falhas antigas, surgimento de fraturas e intenso magmatismo, além da criação de uma "nova geração" de bacias sedimentares, principalmente ao longo da margem continental do Atlântico, que caracterizaram essa etapa mesozoica e foram fundamentais para a configuração morfoestrutural atual da região noroeste do Ceará.
}

Sendo assim, o arranjo estrutural do evento de abertura do Atlântico Sul foi herdado, principalmente, dos ciclos Transamazônico e Brasiliano (Moura-Fé, 2017), na qual a Falha Arapá está integrada. Nesse contexto, infere-se que esse período de reativação tectônica mesozoica atuou enquanto agente estrutural nas rochas do Grupo Serra 
Grande, criando uma rede de diácleses com orientação preferencial no sentido NWSE, possibilitando a configuração atual do Geossítio Paredões de Janeiro.

Atribui-se como analogia ao GPJ o trabalho de Barbosa e Furrier (2012), que abordam a influência de diácleses na configuração do relevo ruiniforme presente no Parque Nacional da Serra da Capivara (Piauí), também esculpidos na Bacia do Parnaíba e com predominância de rochas do Grupo Serra Grande. Os autores salientam que a rede de diáclese, que orientam a evolução geomorfológica local, é fruto de reativações mesozoicas de traços estruturais do embasamento pré-cambriano (falhas e zonas de ruptura) onde se destacam as falhas de Patos, Pernambuco e Senador Pompeu. As zonas de diácleses auxiliam na evolução geomorfológica ruiniforme ao orientar a erosão pluvial.

No GPJ é possível visualizar um processo semelhante ao supracitado, na Fenda do riacho da Rocha da Rosa, onde se nota que a queda d'água da cachoeira é realizada tanto pelo exterior do paredão rochoso, como no interior de fratura (diaclase). Com o tempo, a ação erosiva da água vai alargando as paredes da fratura e em conjunto com a ação da gravidade permite o solapamento de blocos. Salienta-se, entretanto, a ausência de estudos aprofundados sobre a evolução tectônica mesozoica local, o que faz necessário alçar de relações com a literatura disponível.

A Fenda da Trilha (Figura 4A) tem início nas coordenadas (UTM) 2844543 Leste e 9590708 Sul e se estende por mais 150 metros no sentido leste-oeste. A sua porção superior é marcada por uma leve curva, mas, posteriormente, a feição assume caráter linear. A fenda começa no nível de base de 737 metros e vai se aprofundando à medida que segue, chegando a paredões com 20 metros de altura.

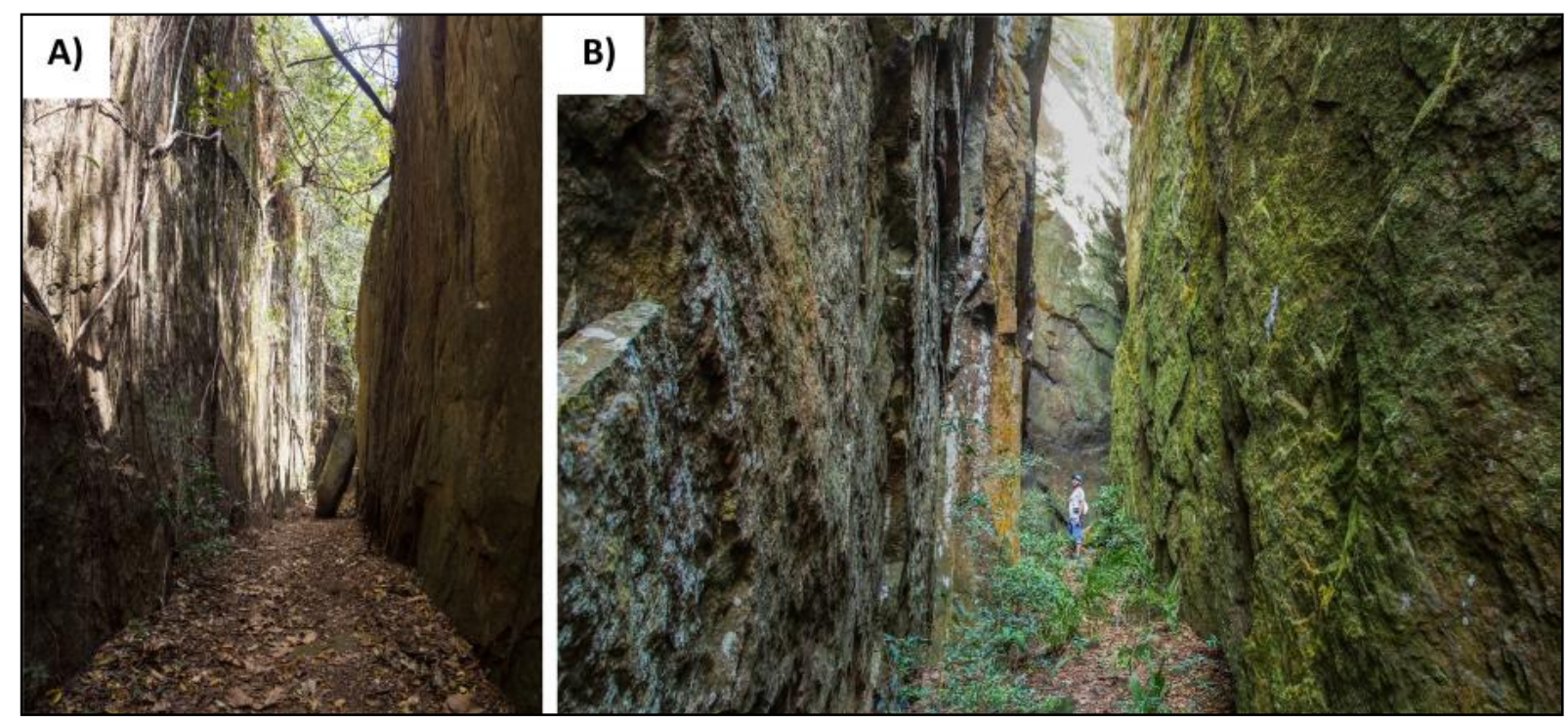

Figura 4: A) Vista da Fenda da Trilha com presença de blocos caídos. B) Fenda Comprida.

No decorrer da Fenda da Trilha há blocos rochosos que solaparam devido à ação da gravidade, o que demonstra o caráter dinâmico da área. É possível notar o acamamento das camadas sedimentares e a presença de fraturamentos que orientam a evolução do relevo local. A toponímia foi atribuída devido à mesma configurar o final 
de uma trilha que conecta o topo do Glint da Ibiapaba às áreas rebaixadas da Depressão Sertaneja, o que confere valor cultural ao espaço.

A Fenda Norte tem seu início nas coordenadas (UTM) 284486 Leste e 9590689 Sul e se estende por aproximadamente 150 metros de forma linear no sentido leste-oeste (Figura 5). A fenda começa no nível de base de 738 metros e se aprofunda à medida que segue para norte, chegando a 20 metros de altura. É possível visualizar o desenho e o perfil da Fenda Norte na Figura 5.

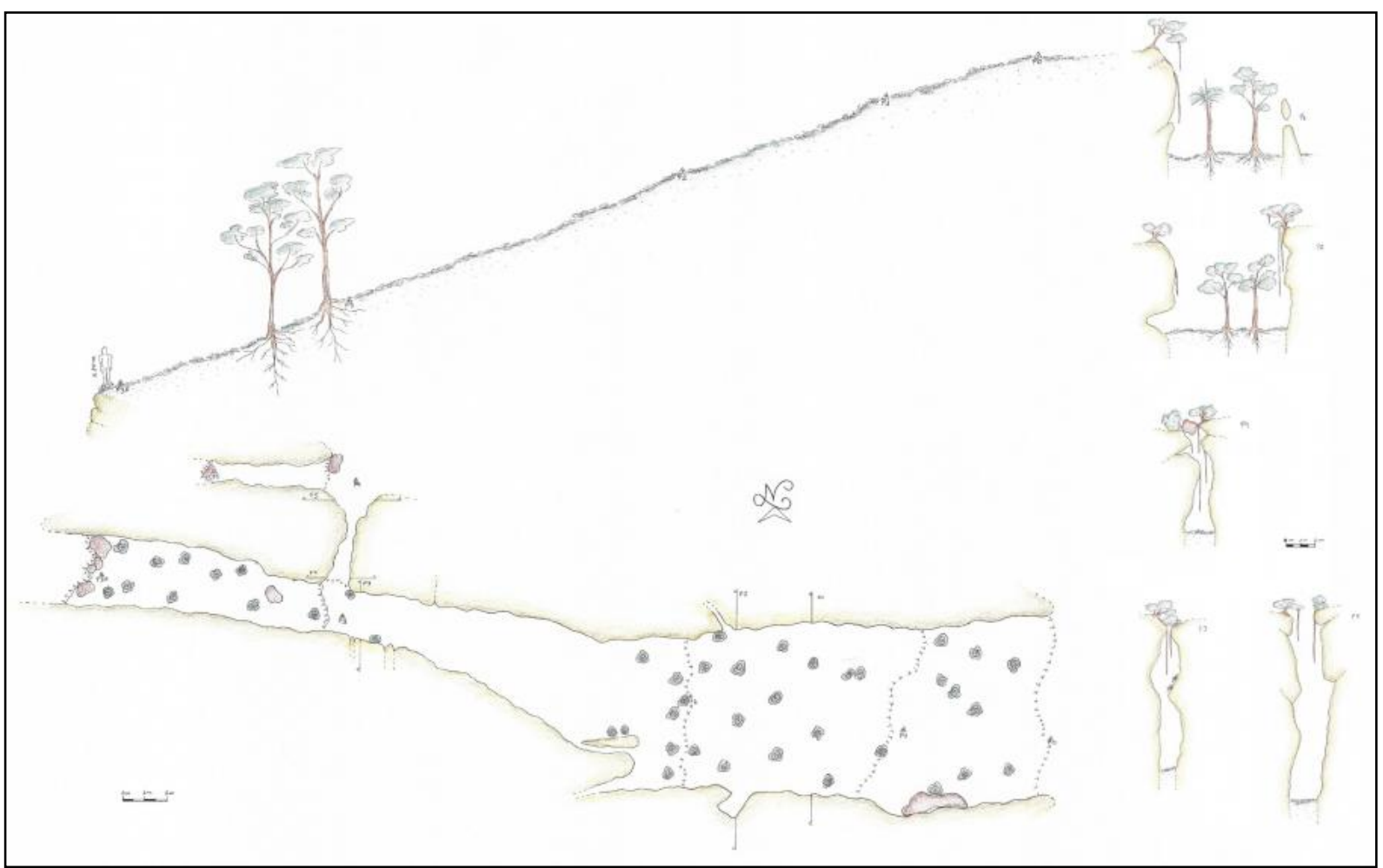

Figura 5: Desenho esquemático e perfis longitudinais da Fenda do Norte.

Mapeamento e desenho: Pedro Edson de Face Moura (2018).

Nas paredes da fenda ocorrem pequenos dutos e alvéolos de dissolução. Um fator relevante é a importância do local para a biota, já que foi visualizado grande número de morcegos e espécies vegetais no interior das fendas, remetendo ao que Gray (2013) classifica enquanto serviço de suporte da geodiversidade.

Na Fenda Norte é possível visualizar feições de caráter ruiniforme, como um arco erodido nas rochas da Formação Tianguá (Figura 5, perfil 1), o qual remete a uma janela, uma vez que dela é possível visualizar a Depressão Sertaneja. Demais feições ruiniformes são caracterizadas por pequenas cavidades que cortam a fenda no sentido leste-oeste, sendo que na porção central ocorre uma de maior desenvolvimento, sendo possível adentrar e transpassar a cornija arenítica e ficar em frente ao contato da Ibiapaba e a Depressão Sertaneja. Também é possível analisar no local um nível de dissolução de característica freática, onde se concentram cavidades semelhantes a pipes. 
A Fenda do riacho da Rocha da Rosa é a que apresenta menor comprimento, seu desenvolvimento vertical chega a 17 metros e 6 metros de largura máxima. Tem início nas coordenadas (UTM) 284636 Leste e 9590465 Sul, numa altitude aproximada de 756 metros, e o ponto final está nas coordenadas (UTM) 284599 Leste e 9590502 Sul. A orientação principal do desenvolvimento da fenda segue em $302^{\circ}$, sendo o grau de declividade em seu interior elevado, chegando aos $40^{\circ}$. Diferente das outras feições, a Fenda do riacho da Rocha da Rosa apresenta um grande número de blocos no seu interior, dificultando o acesso ao final da mesma. No interior da fenda, durante a quadra chuvosa, é formada a cachoeira do riacho da Rocha da Rosa, remetendo grande apelo cênico ao local. $O$ trabalho hídrico ocasiona erosão diferencial na porção final da fenda, que apresenta um recuo.

A maior fenda do GPJ é a Fenda Comprida, a qual ultrapassa os 200 metros de extensão (Figura 4B). O início da fenda está nas coordenas (UTM) 284668 Leste e 9590458 Sul, numa altitude aproximada de 764 metros, enquanto o ponto final está nas coordenadas (UTM) 284799 Leste e 9590433, a 746 metros. O sentido preferencial da fenda segue a orientação de $280^{\circ}$, sendo que na parte final há um pequeno desvio acompanhando zonas de maior fraturamento. A grandiosidade da feição, que apresenta largura entre 2,25 e 6,10 metros e altura máxima de 22,50 metros, a fácil visualização dos elementos de interesse e a preservação torna o local propício para práticas educativas. No final da fenda é possível visualizar a porção retilínea da escarpa e a cornija arenítica.

O mirante sobre a Fenda Comprida está sob as coordenadas (UTM) 284752 Leste e 9590449 Sul, a 758 metros de altitude. O mirante está localizado sobre a parede externa da Fenda Comprida, descrita anteriormente. Para chegar até ele é necessário que no começo da feição, em vez de seguir o caimento topográfico, continuar a trilha sobre a área elevada. Do mirante é possível, além de contemplar a paisagem em direção à depressão, visualizar a Fenda Comprida de cima. Como na Pedra do Espia, é possível notar uma variedade de elementos geomorfológicos, mas tal fato não torna a visita repetitiva, uma vez que o mirante se localiza no extremo de um anfiteatro erosivo diferente. O recuo em questão é mais fechado, diminuindo o horizonte nos sentidos norte e sul, propiciando proximidade com os elementos de interesse didático, facilitando a abordagem, em especial ao afloramento da cornija arenítica.

\section{Avaliação do Geossítio Paredões de Janeiro}

Como atividade de completo ao inventário, foi realizada a avaliação quantitativa dos potenciais científico, turístico e educativo do Geossítio Paredões de Janeiro. Quanto ao Valor Científico o GPJ apresentou avaliação de 285 pontos (Tabela I). O alto potencial científico advem dos bons resultados nos critérios de representatividade e raridade, sendo o único local com presença de fendas estruturais. Por sua vez, o resultado também foi impulsionado pela diversidade de temáticas abordadas que parte dos aspectos geomorfológicos, pedológicos e hidrológicos. 
Tabela I: Avaliação quantitativa do Geossítio Paredões de Janeiro.

\begin{tabular}{|c|c|c|c|c|c|}
\hline Classificação & $\begin{array}{c}\text { Valor } \\
\text { Científico }\end{array}$ & $\begin{array}{c}\text { Valor } \\
\text { Educativo }\end{array}$ & Valor Turístico & $\begin{array}{c}\text { Risco de } \\
\text { Degradação }\end{array}$ & $\begin{array}{c}\text { Prioridade de } \\
\text { Proteção }\end{array}$ \\
\hline $\begin{array}{c}\text { Geossítio de } \\
\begin{array}{c}\text { Relevância } \\
\text { Nacional }\end{array}\end{array}$ & $\begin{array}{c}285 \\
\text { (Geossítio) }\end{array}$ & $\begin{array}{c}305 \text { (Relevância } \\
\text { Nacional) }\end{array}$ & $\begin{array}{c}255 \text { (Relevância } \\
\text { Nacional) }\end{array}$ & $\begin{array}{c}120 \\
\text { (Risco Baixo) }\end{array}$ & $\begin{array}{c}402 \\
\text { (Médio Prazo) }\end{array}$ \\
\hline
\end{tabular}

O Valor Educativo obteve 305 pontos, configurando um local de relevância nacional (Tabela I). Os parâmetros de diversidade geológica, potencial didático e as condições de observação alcançaram a nota máxima, em contrapartida a acessibilidade obteve nota mínima devido à dificuldade de acesso ao local. O alto potencial didático é dado pela diversidade de locais potenciais e temas, especialmente os pontos panorâmicos. O menor valor de uso alcançado pelo Geossítio Paredões de Janeiro foi o referente ao turístico, com 255 pontos (Tabela I). O potencial de divulgação do local é extenso, contrastando com a pouca divulgação e o acesso. Cabe a popularização do geossítio diante atividades relacionadas às práticas de turismo já instituídas no PNU.

O Risco de Degradação é baixo, alcançando o valor de 120 (Tabela I). O reduzido potencial de deterioração dos elementos geológicos de interesse e o fato da área estar localizada em uma unidade de conservação, mesmo que não haja controle de acesso efetivo, contribui para o baixo índice. Quanto à Prioridade de Proteção, que mescla as potencialidades e as vulnerabilidades, o geossítio apresenta a necessidade de ações a médio prazo, especialmente devido ao baixo risco de degradação.

$\mathrm{Na}$ pesquisa base do presente trabalho foram inventariados onze locais de interesse geológico, sendo que desses oito adquiriram o status de geossítio ao alcançar mais de duzentos pontos no valor científico. Com base nos dados foi possível realizar uma comparação entre os geossítios (Tabela II), sendo que para tal foram listadas as colocações de acordo com o parâmetro avaliativo, tendo como lógica que quanto menor a pontuação final melhor a colocação $\left(1^{\circ}\right.$ colocação $=1$ ponto, $2^{\mathrm{a}}$ colocação $=$ 2 pontos, etc.). Essa classificação objetiva trazer uma visão integradora das potencialidades de cada local inventariado.

Segundo a classificação o GPJ configura o quinto mais bem colocando, tendo destaque o seu valor científico, que desponta na terceira posição. Por sua vez, os valores turísticos e educativo não se sobressaíram no contexto do PNU, estando na sexta e oitava posição, respectivamente. Entretanto é válido salientar que o fato é fruto da logística que envolve a visita ao GPJ, o que não permite boa pontuação em critérios relacionados à acessibilidade, diferentemente da maioria dos outros sítios inventariados que estão próximos de vias asfaltadas. 
Tabela II: Ponderação final dos valores obtidos na avaliação quantitativa.

\begin{tabular}{|c|c|c|c|c|c|}
\hline & $\begin{array}{c}\text { Valor } \\
\text { Científico }\end{array}$ & $\begin{array}{c}\text { Valor } \\
\text { Educativo }\end{array}$ & $\begin{array}{c}\text { Valor } \\
\text { Turístico }\end{array}$ & $\begin{array}{c}\text { Risco de } \\
\text { Degradação }\end{array}$ & $\begin{array}{c}\text { Ponderação } \\
\text { Final }\end{array}$ \\
\hline $\begin{array}{c}\text { Geossítio Trilha Ubajara- } \\
\text { Araticum }\end{array}$ & $1^{\circ}$ colocado & $11^{\circ}$ colocado & $9^{\circ}$ colocado & $3^{\circ}$ colocado & $\begin{array}{c}6^{\circ} \text { Lugar } \\
(24 \text { pontos })\end{array}$ \\
\hline $\begin{array}{c}\text { Sítio da Geodiversidade } \\
\text { Sítio do Bosco }\end{array}$ & $10^{\circ}$ colocado & $5^{\circ}$ colocado & $5^{\circ}$ colocado & $8^{\circ}$ colocado & $\begin{array}{c}8^{\circ} \text { Lugar } \\
(28 \text { pontos })\end{array}$ \\
\hline $\begin{array}{c}\text { Geossítio Paredões de } \\
\text { Janeiro }\end{array}$ & $3^{\circ}$ colocado & $8^{\circ}$ colocado & $6^{\circ}$ colocado & $6^{\circ}$ colocado & $\begin{array}{c}5^{\circ} \text { Lugar } \\
(23 \text { pontos })\end{array}$ \\
\hline $\begin{array}{c}\text { Geossítio Cachoeira do } \\
\text { Pinga }\end{array}$ & $5^{\circ}$ colocado & $7^{\circ}$ colocado & $\begin{array}{c}8^{\circ} \\
\text { colocado }\end{array}$ & $7^{\circ}$ colocado & $\begin{array}{c}7^{\circ} \text { Lugar } \\
(27 \text { pontos })\end{array}$ \\
\hline $\begin{array}{c}\text { Geossítio Mirante da } \\
\text { Gameleira }\end{array}$ & $4^{\circ}$ colocado & $3^{\circ}$ colocado & $2^{\circ}$ colocado & $1^{\circ}$ colocado & $\begin{array}{c}1^{\circ} \text { Lugar } \\
(10 \text { pontos })\end{array}$ \\
\hline $\begin{array}{c}\text { Geossítio Mirante do } \\
\text { Pendurado }\end{array}$ & $7^{\circ}$ colocado & $1^{\circ}$ colocado & $\begin{array}{c}4^{\circ} \\
\text { colocado }\end{array}$ & $4^{\circ}$ colocado & $\begin{array}{c}4^{\circ} \text { Lugar } \\
(16 \text { pontos })\end{array}$ \\
\hline $\begin{array}{c}\text { Geossítio Circuito das } \\
\text { Cachoeiras }\end{array}$ & $7^{\circ}$ colocado & $3^{\circ}$ colocado & $2^{\circ}$ colocado & $1^{\circ}$ colocado & $\begin{array}{c}2^{\circ} \text { Lugar } \\
(13 \text { pontos })\end{array}$ \\
\hline $\begin{array}{c}\text { Sítio da Geodiversidade } \\
\text { Cachoeira do Pinguruta }\end{array}$ & $9^{\circ}$ colocado & $9^{\circ}$ colocado & $\begin{array}{c}9^{\circ} \\
\text { colocado }\end{array}$ & $5^{\circ}$ colocado & $\begin{array}{c}9^{\circ} \text { Lugar } \\
(32 \text { pontos })\end{array}$ \\
\hline $\begin{array}{c}\text { Geossítio Cachoeira do } \\
\text { Pajé }\end{array}$ & $6^{\circ}$ colocado & $10^{\circ}$ colocado & $\begin{array}{c}11^{\circ} \\
\text { colocado }\end{array}$ & $10^{\circ}$ colocado & $\begin{array}{c}11^{\circ} \text { Lugar } \\
(37 \text { pontos })\end{array}$ \\
\hline \begin{tabular}{c} 
Geossítio Gruta de Ubajara \\
\hline $\begin{array}{c}\text { Sítio da Geodiversidade } \\
\text { Furnas de Araticum }\end{array}$
\end{tabular} $1^{\circ}$ colocado & $2^{\circ}$ colocado & $1^{\circ}$ colocado & $9^{\circ}$ colocado & $\begin{array}{c}2^{\circ} \text { Lugar } \\
(13 \text { pontos })\end{array}$ \\
\hline
\end{tabular}

\section{Propostas de conservação e valorização do Geossítio Paredões de Janeiro}

As medidas de conservação compreendem o conjunto de propostas elencadas para os geossítios com base na sua configuração ambiental, vulnerabilidade e cenário legal de proteção. Entende-se que essas medidas são uma forma de valorização do geopatrimônio ao buscar a manutenção das potencialidades dos geossítios por meio de propostas (e intervenções práticas) de conservação dos elementos e dos processos associados, entrando em consonância com os objetivos das Unidades de Conservação (UC) e os pressupostos da temática da Geoconservação.

Quanto à questão legal, o Geossítio Paredões de Janeiro está inserido em uma UC de proteção integral, o que limita os tipos de uso. Entretanto, o fato do GPJ estar localizado na área de expansão recente do PNU, realizada no ano de 2002, traz algumas características como a ausência de controle de acesso, de cercamento e de desapropriação. No local existe apenas a parceria com um morador local para a realização do recenseamento dos visitantes. $O$ intercâmbio entre a gestão da UC e a comunidade, incentiva a população a agir enquanto vigia em prol da conservação ambiental, salientando que eles são parte fundamental nesse processo.

O GPJ é um dos locais prioritários na área expandida para a inserção de atividades turísticas e educativas. Caso ocorra o incremento de visitação, torna-se válida a construção de uma portaria no começo da trilha, para um maior controle de acesso, sendo que a mesma deve ser gerida pela população local. A instituição de uma taxa simbólica revertida para a comunidade e para a manutenção do local, também é uma prática viável. Faz-se necessário, de forma imediata, a readequação da trilha que leva 
até a Pedra do Espia, já que em alguns pontos há processos erosivos acentuados. É viável a instituição de uma trilha circular, o que acarretaria em uma menor compactação do solo e erosão laminar, além de propiciar maior dinamicidade ao atrativo turístico. Quanto à mitigação dos processos erosivos citados, também podem ser construídos canais para escoamento das águas pluviais, de acordo com a declividade do local.

As medidas de valorização compreendem ações relacionadas à informação e à interpretação dos geossítios, possibilitando que os visitantes reconheçam os seus valores (Brilha, 2005). As propostas de valorização devem compreender ações de contexto local, buscando a tradução do ambiente em uma linguagem passível de entendimento pelo público e capacitando o geossítio por meio de estruturas físicas ou sociais para o incremento de sua visitação.

Como medida de valorização do GPJ são propostos dois painéis interpretativos. Os painéis são meios não-personalizados (não-guiados) de interpretação. Enquanto os meios personalizados são o conjunto de ações que englobam a interação entre o público e uma pessoa que assume o papel de "interprete" do patrimônio, os meios não-personalizados são aqueles sem a necessidade de um interprete, sendo assentados sobre o uso de objetos e aparatos. A vantagem desse grupo está no fato de serem autoexplicativos. Por "sempre estarem disponíveis, garantem a transmissão da mensagem planejada e podem atender a um grande número de visitantes". Em contrapartida, as desvantagens partem da "impossibilidade de esclarecimento de dúvidas, a dificuldade em manter o interesse e estão sujeitos ao vandalismo" (Moreira, 2012, p. 91). Outros exemplos de meios não-personalizados são as trilhas autoguiadas, os folhetos interpretativos, os guias de campo e os materiais audiovisuais.

Quanto aos painéis interpretativos, foi necessário construir propostas teóricas sobre os temas a serem tratados, uma vez que as possibilidades são inúmeras. A delimitação do tema principal de objetivos específicos é papel fundamental na elaboração de materiais interpretativos. As características teóricas das propostas são explanadas no plano interpretativo presente no Tabela III. O primeiro painel trata dos aspectos geomorfológicos do mirante da Pedra do Espia (Figura 6), traçando relações entre estrutura (litologia) e forma. Abordagens sobre os principais tipos de rochas existentes nas porções superiores do Glint da lbiapaba e aquelas que compõem a depressão sertaneja são realizadas, alçando o potencial cênico do mirante. O mesmo deve ser colocado em um descampado localizado em frente à Pedra do Espia, e não sobre o afloramento. 
Potencialidades do Geossítio Paredões de Janeiro, Parque Nacional de Ubajara, Ceará, Brasil Geoconservação e Património Natural

Tabela III: Plano interpretativo para a valorização do Geossítio Paredões de Janeiro.

\begin{tabular}{|c|c|c|}
\hline & Painel Pedra do Espia & Painel Fenda Norte \\
\hline $\begin{array}{l}\text { O que interpretar? } \\
\text { (Escolha do tema principal) }\end{array}$ & $\begin{array}{l}\text { O fato do Mirante permitir diferenciar as } \\
\text { principais feições geomorfológicas do front } \\
\text { da Ibiapaba e da Depressão Sertaneja. }\end{array}$ & $\begin{array}{l}\text { Que as fendas são feições } \\
\text { oriundas da erosão localizadas } \\
\text { em zonas de fraturas } \\
\text { originadas por eventos } \\
\text { tectônicos. }\end{array}$ \\
\hline $\begin{array}{c}1 \text { - O que pretende que se } \\
\text { conheça? }\end{array}$ & $\begin{array}{c}\text { O nome e as características de algumas } \\
\text { feições geomorfológicas comuns no Parque } \\
\text { Nacional de Ubajara (escarpa, vertente, } \\
\text { inselberg). }\end{array}$ & $\begin{array}{l}\text { A relação relevo e litologia e o } \\
\text { caráter dinâmico do mesmo, } \\
\text { tendo como foco a evolução } \\
\text { das fendas }\end{array}$ \\
\hline $\begin{array}{c}2 \text { - O que se pretende que } \\
\text { se sinta? }\end{array}$ & \multicolumn{2}{|c|}{$\begin{array}{l}\text { - Sejam sensibilizados no que tange à conservação ambiental do PNU e fiquem } \\
\text { impactados pelas descrições do relevo e dos processos que levaram à sua } \\
\text { configuração. } \\
\text { - Se sintam intrigados a buscar mais informações sobre geomorfologia no seu } \\
\text { dia-a-dia. }\end{array}$} \\
\hline Quem será o público alvo? & \multicolumn{2}{|c|}{$\begin{array}{l}\text { - Turistas ocasionais que vão aos Paredões do Janeiro (a sua maioria sem } \\
\text { auxílio de guia ou com conhecimento aprofundado sobre o local). } \\
\text { - Grupos de estudantes de ensino fundamental e médio das cidades } \\
\text { circunvizinhas. } \\
\text { - Grupos de estudantes da área das Geociências. }\end{array}$} \\
\hline Usos sugeridos & \multicolumn{2}{|l|}{ - Turístico, educativo e científico. } \\
\hline
\end{tabular}

\section{Geopatrimônio}

Parque Nacional de Ubajara

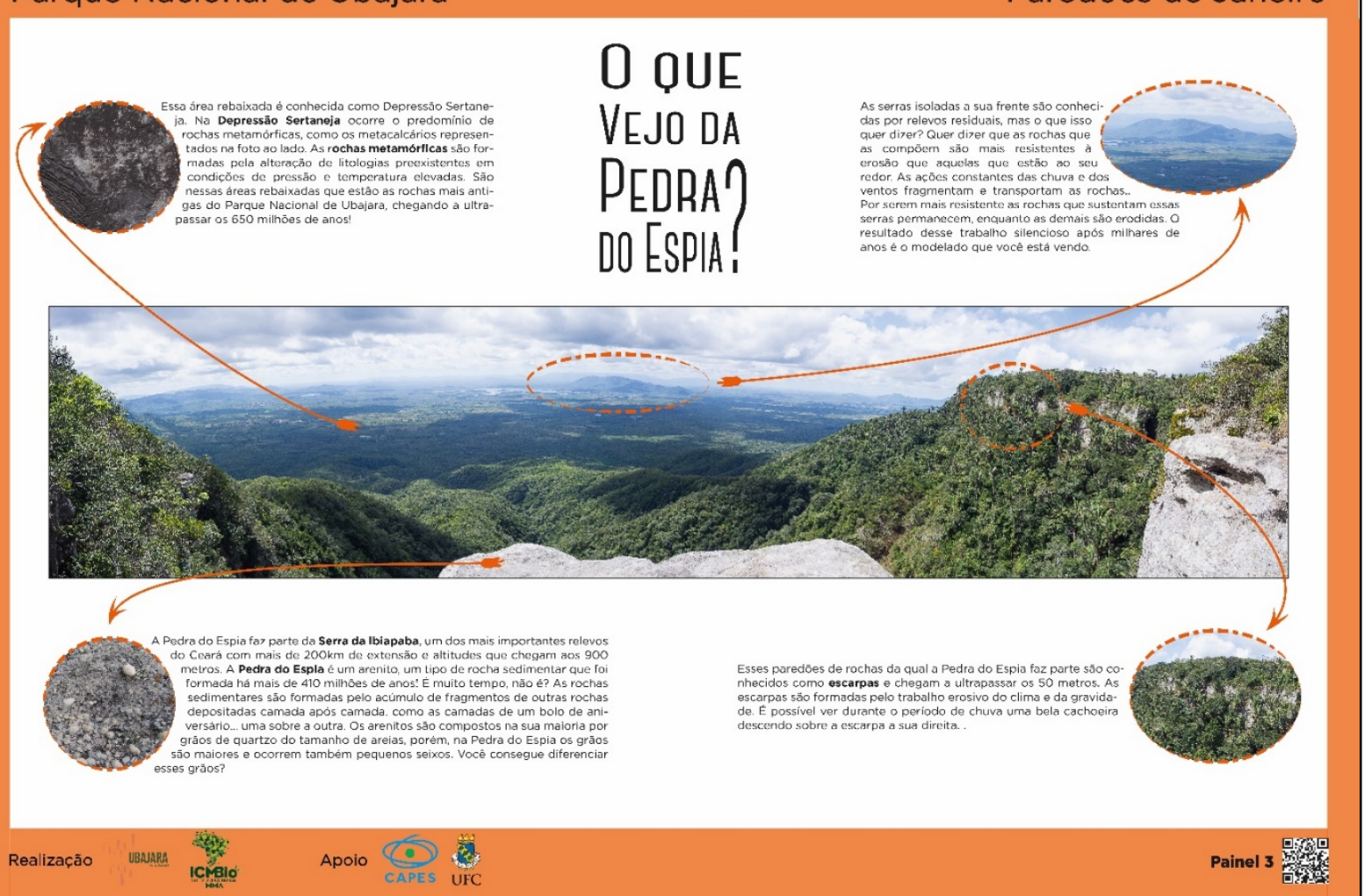

Figura 6: Painel interpretativo sobre a Pedra do Espia localizada no Geossítio Paredões de Janeiro.

Por sua vez, o segundo painel aborda o desenvolvimento da Fenda Norte (Figura 7), remetendo à incógnita sobre a gênese e evolução dessa feição geomorfológica característica do GPJ, sendo fixado no começo da feição. Os temas abordados partem da gênese e evolução das fendas estruturais, alçando de temas complexos como reativações tectônicas, mas de forma passível de entendimento ao grande público. 


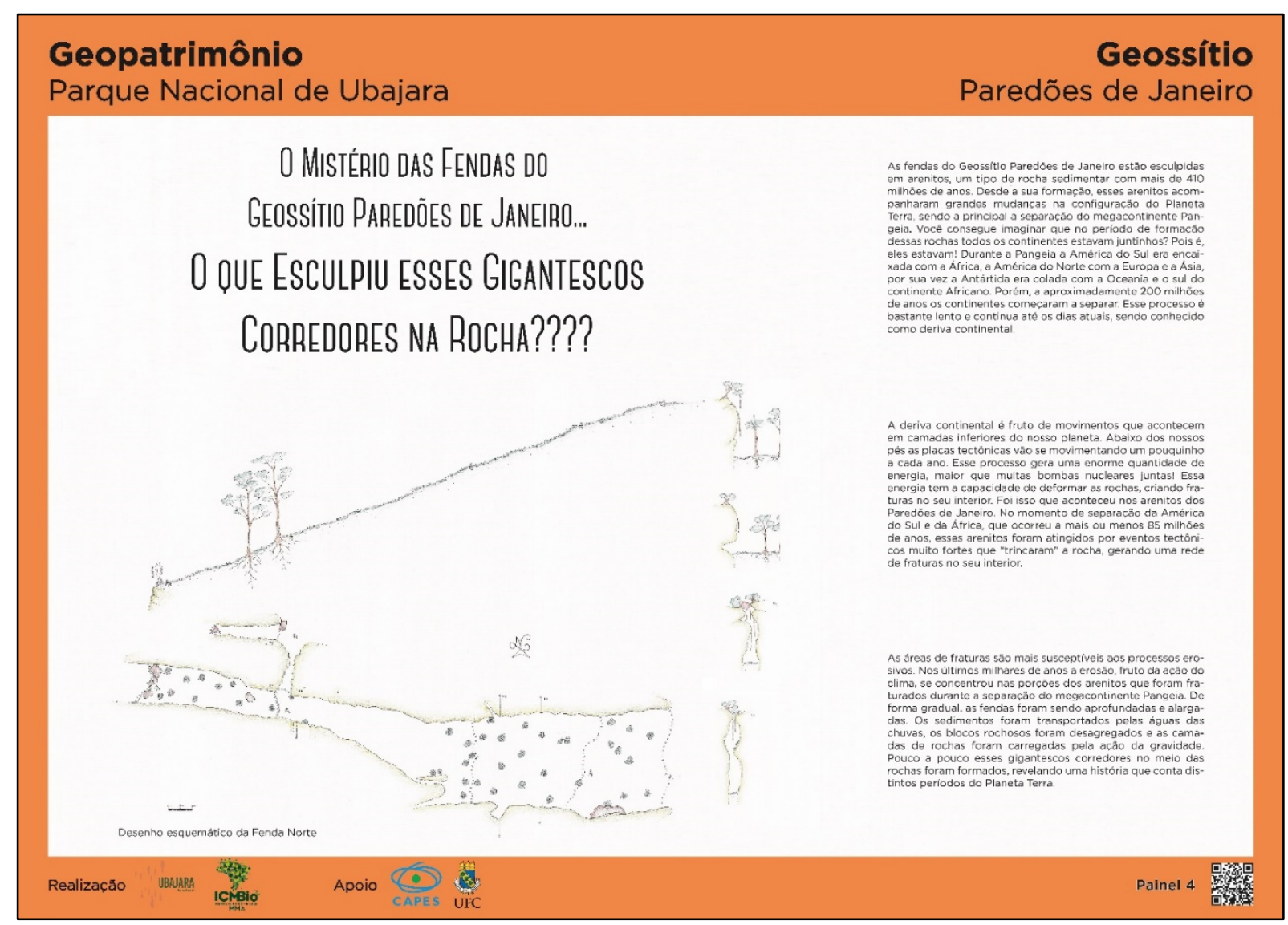

Figura 7: Painel interpretativo sobre a Fenda Norte, localizada no Geossítio Paredões de Janeiro.

Os painéis interpretativos seguem o mesmo layout, apresentando dimensões de $105 \mathrm{~cm}$ de comprimento por $75 \mathrm{~cm}$ de altura. É sugerida a confecção em formato de uma mesa inclinada, ocasionando menos interferência na visualização da paisagem e dos elementos de interesse interpretados. Para a produção da base são propostas as rochas da região, arenitos silicificados e ardósias, por apresentarem boa resistência aos agentes intempéricos, ou madeira, que apesar de não apresentar a mesma resistência, configura uma opção durável e com preço acessível. Propõe-se ainda a utilização de acrílico ou policarbonato, materiais resistentes a variações de temperaturas e ao impacto, para revestir a impressão, tornando-a mais durável.

Nos layouts dos painéis da Pedra do Espia (Figura 6) e da Fenda Norte (Figura 7) foi utilizada a tipografia Gotham, comum na produção de materiais gráficos por facilitar a leitura. Quanto ao tamanho das letras, levou-se em conta a distância entre o leitor e os painéis interpretativos, adotando uma dimensão passível de visualização de uma distância de 1,5 metros. Sendo assim toda a tipografia apresenta dimensões superiores a $24 \mathrm{pt}$. Os textos foram confeccionados em uma linguagem simples e convidativa, buscando a utilização de 200 a 300 palavras por texto, conforme é orientado em manuais temáticos (Projeto Doces Matas, 2002). O uso de imagens, em detrimento de texto, facilita a interpretação dos leitores, especialmente ao poder relacionar o painel com a paisagem que os cercam. 


\section{Propostas de divulgação do Geossítio Paredões de Janeiro}

As estratégias de divulgação para o GPJ apresentam caráter integrador e amplo, constituem ferramentas embasadas nos princípios da geocomunicação e que buscam levar a importância das feições geológicas e geomorfológicas para além do perímetro da UC, sendo meios de incentivar a visita ao local. A divulgação do geopatrimônio deve ser pensada como uma forma de ultrapassar os limites geográficos do geossítio, expandindo o conhecimento sobre o mesmo e consolidando o senso de lugar.

Para a valorização do Geossítio Paredões de Janeiro foram pensadas duas estratégias de fácil aplicação pelo órgão gestor do Parque Nacional de Ubajara. A primeira compreende a confecção de um cartão postal com texto interpretativo, e a segunda, a inserção do GPJ em roteiros geoturísticos que contemplam o geopatrimônio local, integrando o conjunto de geossítios supracitados.

A confecção de cartões postais como ferramenta de divulgação do geopatrimônio configura uma estratégia de baixo custo e alta capacidade de propagação. Além de se apresentarem como lembranças comuns e difundidas em locais turísticos, os cartões postais apresentam um público variado já que as informações presentes são passadas tanto para as pessoas que visitaram o local (remetente) como para os seus destinatários. Moreira (2012, p. 93) expõe que em muitos locais os cartões postais "utilizam fotos de paisagens dominadas por elementos significativos do Patrimônio Geológico, e não incluem nem mesmo uma frase sobre a paisagem", o que configura uma perda da capacidade educativa e uma superficialidade da ferramenta diante da crescente busca dos turistas em saber o que compõe a paisagem, indo além da mera contemplação.

O cartão postal do GPJ apresenta dimensões tradicionais de 10x15cm (10 centímetros de altura por 15 de comprimento). A frente é composta por uma imagem da Fenda Comprida e o título "Parque Nacional de Ubajara" em tipografia Caviar Dreans Italic 22pt (Figura 8). No verso foi colocada em evidência a frase "Descubra-se no Geopatrimônio do Parque Nacional de Ubajara" na tipografia Geosans Light 14pt, no intuito de chamar a atenção do visitante (Figura 8).

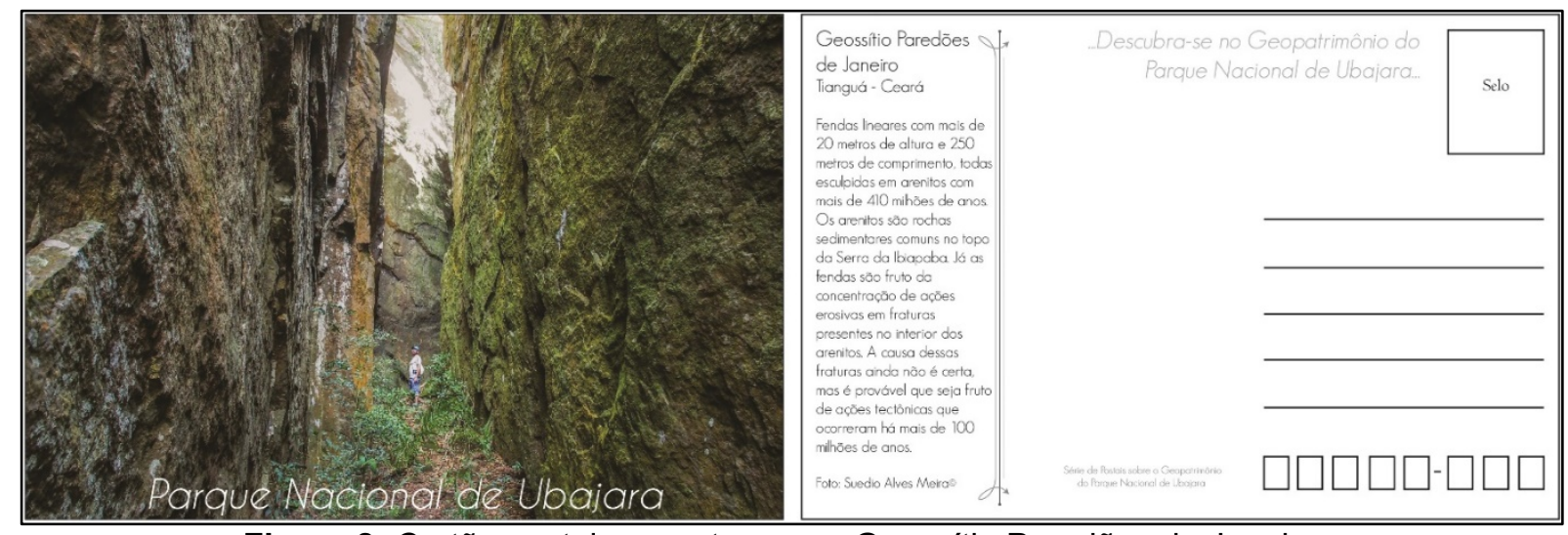

Figura 8: Cartão postal proposto para o Geossítio Paredões de Janeiro. 
O texto interpretativo está localizado no lado esquerdo do verso do postal, logo abaixo do nome e localização do geossítio e acima do autor da fotografia. Foi utilizada a tipografia Geosans Light para o título, localização, texto e autoria, com tamanhos de 12, 10, 9 e 8 pt, respectivamente. O texto interpretativo tem como objetivo central abordar as fendas estruturais que se desenvolvem pelo geossítio, sendo o mesmo: "Fendas lineares com mais de 20 metros de altura e 250 metros de comprimento, todas esculpidas em arenitos com mais de 410 milhões de anos. Os arenitos são rochas sedimentares comuns no topo do Planalto da lbiapaba. Já as fendas são fruto da concentração de ações erosivas em fraturas presentes no interior dos arenitos. A causa dessas fraturas ainda não é certa, mas é provável que seja fruto de ações tectônicas que ocorreram há mais de 100 milhões de anos" (Figura 8).

No lado direito do verso há um espaço reservado ao selo, escrita com linhas e código postal. A porção central é um vazio destinado à escrita livre. Abaixo desse vazio há escrito "série de postais sobre o Geopatrimônio do Parque Nacional de Ubajara" no intuito de salientar ao leitor que outros cartões estão disponíveis. Salienta-se que 30 cópias do presente cartão postal foram distribuídas gratuitamente durante festividades do aniversário de 60 anos do Parque Nacional de Ubajara no mês de abril de 2019.

Os roteiros geoturístico propostos para o Parque Nacional Ubajara integram todos os onze geossítios inventariados por Meira (2019, no prelo) ${ }^{2}$. A estratégia parte do entendimento que as práticas turísticas realizadas são orientadas ao segmento do ecoturismo, não sendo uma proposta de mudança desse paradigma, mas sim uma ferramenta para a dinamização da oferta turística e para o melhor uso das potencialidades ambientais presentes.

Os roteiros foram formulados com base nos interesses e no tempo que os visitantes despendem no PNU. São propostos roteiros com duração de dois e três dias, e um de cunho científico, que não indica uma sequência para a visitação dos geossítios. Os dois primeiros roteiros foram pensados para um público de "geoturistas acidentais", que descobrem o geopatrimônio e suas potencialidades por acaso, apresentando pouco ou nenhum conhecimento específico sobre processos relacionados à geologia e à geomorfologia (Hose, 1996). O roteiro de dois dias permite visitar sete geossítios e o de três dias nove geossítios, sendo que o GPJ está presente em todos os roteiros.

Por sua vez, o roteiro científico foi construído para um público que busca conhecimento específico sobre o geopatrimônio do PNU, integrando geossítios que abordam temas de maior complexidade. O roteiro é orientado a grupos educativos, grupos de adultos não especializados, que procuram informações específicas, ou para grupos de pessoas aficionadas e especializadas. O roteiro científico contempla os onze geossítios inventariados.

Com base nos roteiros definidos foram confeccionados três folhetos turísticoeducativos no programa Adobe Illustrator CC 2015. Os folhetos apresentam layout

\footnotetext{
${ }^{2}$ Meira, S. A. (2019, no prelo). Planejamento e propostas de valorização do geopatrimônio do Parque Nacional de Ubajara, Ceará, Brasil. Tese (Doutorado em Geografia) - Universidade Federal do Ceará, Programa de Pós-Graduação em Geografia, Fortaleza.
} 
semelhante (Figura 9), com adaptações pontuais nos textos da capa, fundo e interior (descrição dos geossítios). Os folhetos são diferenciados pela cor adotada, sendo o de dois dias na coloração roxa, o de três dias laranja e o científico vermelho.

É proposto que os folhetos sejam impressos em folha tamanho A4 (210 por 297mm), dobrado em três partes (totalizando seis faces). Os textos empregados foram revisados por uma profissional da área de publicidade e propaganda, com objetivo de trazer maior fluidez na leitura e a adaptação das terminologias científicas para um vocabulário do cotidiano, mas sem perder a capacidade informativa.

As partes externas apresentam títulos e textos chamativos, buscando conquistar a curiosidade do leitor. A frase da capa "Descubra-se no Geopatrimônio do Parque Nacional de Ubajara", ou mesmo a alusão ao tempo geológico na oração "Conheça 600 milhões de anos de história em um dos mais belos Parques Nacionais do Brasil. Vivas as suas paisagens, cores, cheiros e cultura. Descubra Ubajara!" (Figura 9), buscam cativar os visitantes a realizar o roteiro, a consumir esse novo produto turístico disponível, em complemento às atividades ecoturísticas habituais. Ainda na porção externa do folheto há uma curta explicação sobre os conceitos de geodiversidade, geossítios e geopatrimônio, termos que aparecem no texto, mas que devido ao seu pouco uso no cotidiano podem trazer confusão aos turistas.

Na porção interna do folheto está a descrição dos geossítios que compõem o roteiro em questão. O pequeno texto interpretativo é acompanhado de uma fotografia e a localização aproximada em um mapa artístico (Figura 10). Os textos foram construídos com base em planos interpretativos previamente elaborados. São sucintos e trazem informações importantes e curiosas sobre os locais, como as idades das rochas, os nomes das feições geomorfológicas de destaque e os principais atores nos processos de formação. É válido salientar que os textos bases sofreram alterações entre os folhetos devido à questão de espaço. Nesse contexto, assim como acontece com a fase externa, cada folheto apresenta pequenas mudanças em sua arte, uma vez que englobam números diferenciados de geossítios. Há um título interno "Roteiro Geoturístico do Parque Nacional de Ubajara" que se interliga com os conceitos apresentados na parte externa (Figura 9).

O texto interpretativo base do Geossítio Paredões de Janeiro é: Mirantes, cachoeiras e fendas esculpidas em rochas. É impossível não se sentir pequeno no interior desses corredores de arenito que ultrapassam 25 metros de altura e 200 de comprimento. Do mirante da Pedra do Espia é possível contemplar a cachoeira do Riacho da Rocha que se projeta para o interior de uma fenda. Local mágico e imperdível! 


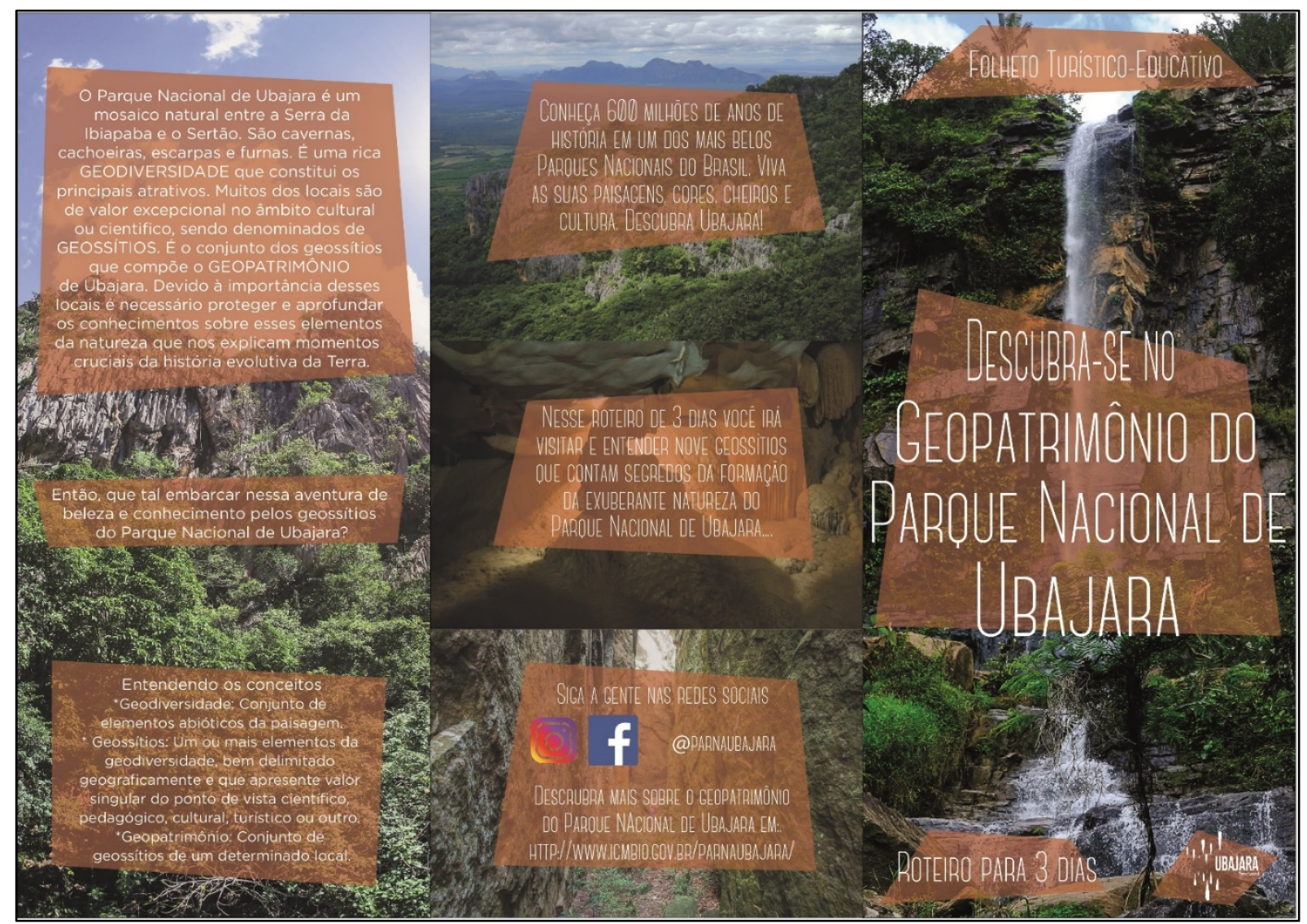

Figura 9: Modelo da parte externa do folheto turístico-educativo.

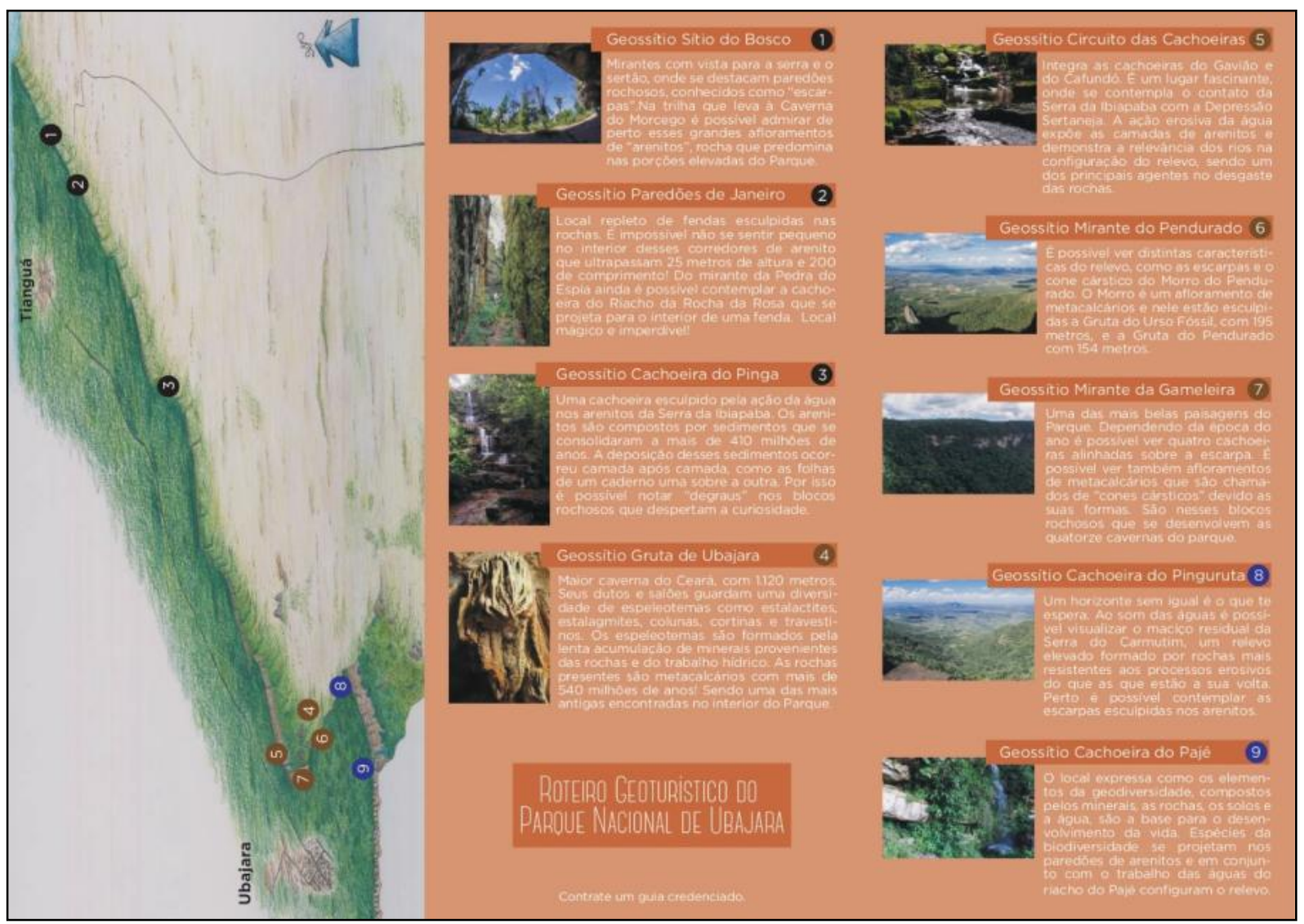

Figura 10: Modelo da parte interna do folheto turístico-educativo Mapa artístico: Pedro Edson de Face Moura (2019) 


\section{Conclusões}

A temática da Geodiversidade, Geopatrimônio e Geoconservação, para além da descrição dos componentes abióticos, estabelece a aplicabilidade enquanto objetivo, ou seja, apresenta caráter prático em seus estudos. No âmbito das mudanças climáticas e da discussão pelas Geociências de uma nova era geológica, o antropoceno, esse tipo de ação adquire relevância ao aproximar as pesquisas das Universidades dos objetivos de conservação estabelecidos por órgãos internacionais, incentivando, assim, um diálogo entre Ciência e Sociedade.

Como apresentado nesse trabalho, cada etapa da estratégia de geocosnervação exibe sua relevância no processo. $O$ inventário dos geossítios pode ser definido enquanto a "alma" da geoconservação, uma vez que delimita quais os elementos abióticos da paisagem que devem ser salvaguardados para as futuras gerações. Um inventário realizado de forma correta, com base em objetivos e métodos bem estabelecidos, facilita a realização das etapas posteriores. A avaliação adquire importância enquanto ferramenta de comparação entre os geossítios, bem como um facilitador do diálogo com os órgãos de gestão territorial.

As etapas finais, compreendidas pelas propostas conservação, valorização e divulgação compreendem as "mãos" e as "vozes" da geoconservação. São as etapas em que os conhecimentos produzidos são traduzidos em propostas palpáveis, que buscam melhorias reais para a conservação do geopatrimônio. Configuram também o momento de transmitir, por meio de uma linguagem adaptada ao ouvinte, os saberes relacionados às Geociências. É válido pontuar que essas etapas devem ser realizadas com maior afinco no meio acadêmico, uma vez que boa parte dos estudos desenvolvidos até então compreendem apenas as etapas de inventário e avaliação, conjunto definido por Borba et al. (2013) enquanto a "geoconservação básica".

O presente trabalho se ergue como modelo a ser replicado em diferentes escalas de análise (local, regional, nacional) e foco (educativo, turístico, científico, etc.). $O$ inventário cumpriu o papel de descrever e tornar conhecidas as potencialidades e vulnerabilidades do Geossítios Paredões de Janeiro, apresentando caráter inédito diante a ausência de estudos prévios. As principais potencialidades partem das feições geomorfológicas excepcionais que se distinguem daquelas encontradas nas proximidades, apresentando apelo cênico e diversidade de temas passíveis de abordagem em atividades educativas. Assim, é correto afirmar que a geomorfologia do Geossítio Paredões de Janeiro se ergue enquanto um patrimônio natural. Quanto ao contributo ao desenvolvimento das Geociências, o local se ergue enquanto espaço propício para estudos na área de geomorfologia estrutural, uma vez que é necessário o aprofundamento do entendimento da origem e evolução da rede de diácleses que orienta a evolução da morfologia das fendas e do front do Glint da Ibiapaba

A avaliação demonstra o elevado potencial científico, educativo e turístico do Geossítio Paredões de Janeiro ao classificá-lo enquanto de relevância nacional em 
todos os critérios. Esses resultados, no contexto da pesquisa de doutorado em que o presente trabalho se insere, adquire importância na comparação entre as áreas de interesse geológico inventariadas, erguendo o Geossítio Paredões de Janeiro enquanto um dos locais prioritários do Parque Nacional de Ubajara ao desenvolvimento de atividades de valorização e divulgação.

As propostas de conservação e valorização demonstram medidas práticas passíveis de aplicação no Geossítio Paredões de Janeiro em prol da melhoria paisagística e no estabelecimento desse sítio enquanto destino para a realização de atividades educativas e como um produto turístico do Parque Nacional de Ubajara. O estabelecimento de novas trilhas e a fixação de painéis interpretativos capacitaria o geossítio ao possibilitar dinamicidade e oferta de atrativos e ao elencar conhecimentos às práticas turísticas. Tais ações auxiliariam na manutenção dos processos naturais por meio da conscientização ambiental, entrando em consonância com o paradigma da sustentabilidade.

Por fim, a divulgação cumpre o papel de mostrar aos visitantes e a aqueles que estão para além dos limites do Parque Nacional de Ubajara a importância da área enquanto registro da história evolutiva regional e enquanto local potencial para atividades educativas e turísticas. A inserção do Geossítio Paredões de Janeiro em três roteiros geoturísticos, onde todos os locais e os temas selecionados se complementam ao apresentar correlações ao entendimento do geopatrimônio, e a produção do cartãopostal traz visibilidade a esse local pouco conhecido e dinamiza a percepção da paisagem do Parque Nacional de Ubajara, a qual é, quase que unicamente, atrelada à Gruta de Ubajara e ao relevo cárstico.

\section{Agradecimentos}

Gostaríamos de agradecer a Pedro Edson de Face Moura pelo desenvolvimento de elementos gráficos presentes no texto.

O presente trabalho foi realizado com apoio da Coordenação de Aperfeiçoamento de Pessoal de Nível Superior - Brasil (CAPES) por meio de bolsas de Doutorado-PROEX (Código de financiamento: 88882.180701/2018-01) e de Doutorado Sanduíche no Exterior (Código de financiamento: 88887.364301/2019-00) concedidas ao autor principal.

\section{Bibliografia}

Barbosa, M. E. F., Furrier, M. (2012). Sistemas de diaclases e influência tectônica da borda sudeste da bacia sedimentar do Parnaíba: Parque Nacional Serra da Capivara, Brasil. Revista do Departamento de Geografia, 23, 250-266. https://doi.org/10.7154/RDG.2012.0023.0011

Borba, A. W., Souza, L. F., Mizusaki, A. M. P., Almeida, D. P. M., Stumpf, P. P. (2013). Inventário e avaliação quantitativa de geossítios: exemplo de aplicação ao patrimônio geológico do município de Caçapava do Sul (RS, Brasil). Pesquisa em Geociências, 40(3), 275-294. https://doi.org/10.22456/1807-9806.77830 
Brilha, J. (2005). Património Geológico e Geoconservação: A Conservação da Natureza na sua Vertente Geológica. Braga: Palimage Editores.

Brilha, J. (2016). Inventory and Quantitative Assessment of Geosite and Geodiversity Sites: a Review. Geoheritage, 8(2), 119-134. https://doi.org/10.1007/s12371-014-0139-3

Caputo, M. V., Lima, E. C. (1984). Estratigrafia, idade e correlação do Grupo Serra Grande Bacia do Parnaíba. In: Anais do XXXIII Congresso Brasileiro de Geologia (pp.740-753). Rio de Janeiro: Universidade Federal do Rio de Janeiro.

Carcavilla, L., Durán, J. J., Lopez-Martínes, J. (2008). Geodiversidade: concepto y relación con el patrimonio geológico. Geo-Temas, 10, 1299-1303.

CPRM (2014). Carta Geológica Folha Frecheirinha (AS-24-Y-C-VI) em escala de 1:100.000. Brasília, DF: CPRM.

CPRM (2018). Geossit: cadastro de sítios geológicos. Disponível em: http://www.cprm.gov.br/geossit

Fuertez-Gutiérrez, I., Fernandes-Martinéz, E. (2010). Geosites Inventory in the Leon Province (Northwestern Spain): A Tool to Introduce Geoheritage into Regional Environmental Management. Geoheritage, 2(1-2), 57-75. https://doi.org/10.1007/s12371-010-0012-y

Garcia-Cortés, A., Carcavilla Urquí, L. C. (2013). Documento metodológico para la elaboracíon del inventario Español de lugares de interés geológico (IELIG). Versíon 18-13-2013. Madrid: Instituto geológico y minero de España.

Góes, A. M. O., Feijó, F. J. (1994). Bacia do Parnaíba. Boletim de Geociências da Petrobrás, 8, 57-67.

Gray, M. (2008). Geodiversity: developing the paradigm. Proceedings of the Geologists' Association, 119(3-4), 287-298. https://doi.org/10.1016/S0016-7878(08)80307-0

Gray, M. (2013). Geodiversity: valuing and conserving abiotic nature (2th ed.). Chichester: John Wiley \& Sons.

Hose, T. A. (1996). Geotourism, or can tourists become casual rock hounds? In Bennet M. R., Doyle P., Larwood J. G., Prooser C. D. (eds.). Geology on your Doorstep. (pp. 207-228). Reino Unido: Geological Society.

Meira, S. A., Morais, J. O. (2016). Os conceitos de Geodiversidade, Patrimônio Geológico e Geoconservação: Abordagens sobre o papel da Geografia no estudo da temática. Boletim de Geografia (UEM), 34(3), 129-147. https://doi.org/10.4025/bolgeogr.v34i3.29481

Moreira, J. C. (2012). Interpretação ambiental, aspectos geológicos e geomorfológicos. Boletim de Geografia, 30(2), 87-98. https://doi.org/10.4025/bolgeogr.v30i2.13694

Moura-Fé, M. M. (2017). Evolução morfoestrutural cretácea da Ibiapaba Setentrional, região Nordeste do Ceará. GeoUERJ, 31, 389-416. https://doi.org/10.12957/geoueri.2017.28327

Nieto, L. M. (2001). Geodiversidad: propuesta de una definición integradora. Boletín Geológico y Minero, 112(2), 3-12. Disponível em: http://asgmi.igme.es/Boletin/2001/112 2-2001/1ARTICULO\%20\%20GEODIVERSIDAD.pdf

Pereira, R. G. F. A. (2010). Geoconservação e desenvolvimento sustentável na Chapada Diamantina (Bahia-Brasil). Tese de Doutoramento em Ciências, Escola de Ciências, Universidade do Minho, Portugal. 
Meira, Nascimento e Silva / Physis Terrae, Vol. 1, $n^{\circ}$ 2, 2019, 21-42

Projeto Doces Matas. (2002). Manual de introdução à interpretação ambiental. Belo Horizonte.

Artigo recebido em/ Received on 05/11/2019

Artigo aceite para publicação em/ Accepted for publication on: 23/12/2019 